\author{
Marek Szajt \\ Politechnika Częstochowska, Polska \\ Czestochowa University of Technology, Poland
}

\title{
Aktywność patentowa państw OECD w ujęciu regionalnym - konwergencja czy utrzymanie status quo
}

\section{Patent Activity of OECD Countries in Regional View - Convergence or Maintaining the Status Quo}

\begin{abstract}
Streszczenie: Celem badań prezentowanych w artykule była analiza poziomu innowacyjności państw OECD na poziomie regionalnym w latach 2000-2011. Zakres czasowy ograniczony jest ze względu na dostępność danych. $W$ badaniach uwzględniono aktywność patentową jako miarę innowacyjności oraz nakłady na działalność $\mathrm{B}+\mathrm{R}$ i zatrudnienie $\mathrm{w}$ sektorze $\mathrm{B}+\mathrm{R}$ jako jej determinanty. Jako narzędzie badawcze wykorzystano wielowymiarową analizę statyczną i modelowanie ekonometryczne. Analizując zmiany w aktywności patentowej na poziomie poszczególnych państw (w podziale na regiony), wykorzystano analizę beta-konwergencji oraz modele przestrzenno-czasowe dla całej grupy państw. Wyniki potwierdziły, że w większości badanych państw obserwuje się pewną konwergencję aktywności, jednak jej istotność możemy potwierdzić jedynie w połowie przypadków. Obserwowana niekiedy dywergencja w żadnym z przypadków nie została potwierdzona jako istotna statystycznie. Można zatem wnioskować o ogólnej tendencji „równania w górę” w zakresie wzrostu poziomu innowacyjności w państwach OECD. Z kolei analiza ekonometryczna umożliwiła wskazanie dystansu pomiędzy aktywnością patentową poszczególnych regionów i państw. Te silniej rozwinięte, mimo zrozumiałego spowolnienia, korzystają z wykreowanego potencjału i trzymają niemal trwały dystans względem pozostałych. W ujęciu ogólnym zmiany dostrzegalne są raczej w obrębie bardziej jednorodnych (pod względem rozwoju) grup niż pomiędzy nimi.
\end{abstract}

\begin{abstract}
The aim of the research presented in the article was to analyze the level of innovation in OECD countries at the regional level in 2000-2011. The time period is limited due to the availability of data. The studies included patent activity as a measure of innovation and expenditures on R\&D and employment in the R\&D sector as its determinants. The analysis of convergence and econometric modeling were used as research tools. When analyzing changes in patent activity at the level of individual countries (by region) beta convergence analysis and models of space-time for the whole group of countries were used. The results confirmed that most of the countries observed a convergence of activity, but its significance can confirm only half of the cases. Divergence sometimes observed in any of the cases has not been confirmed as statistically significant. Therefore, there can be inferred an existence of a general trend 'top runner' in terms of growth in the level of innovation within the OECD countries. In turn, econometric analysis also identified a gap between patent activity of individual regions and countries. Stronger developed regions, despite the understandable slowdown, benefit from the created potential and maintain almost constant distance in relation to the others.
\end{abstract}


In general, the changes are more noticeable within more homogeneous (in terms of development) groups than between them.

Słowa kluczowe: aktywność patentowa; konwergencja; model przestrzenno-czasowy; OECD; regiony Keywords: convergence; OECD; patent activity; regions; spatio-temporal model

Otrzymano: 18 grudnia 2016

Received: 18 December 2016

Zaakceptowano: 20 sierpnia 2017

Accepted: 20 August 2017

Sugerowana cytacja / Suggested citation:

Szajt, M. (2017). Aktywność patentowa państw OECD w ujęciu regionalnym - konwergencja czy utrzymanie status quo. Prace Komisji Geografii Przemysłu Polskiego Towarzystwa Geograficznego, 31(4), 40-51. https:// doi.org/10.24917/20801653.314.3

\section{WSTĘP}

Przejście z gospodarki opartej na rolnictwie i produkcji ciężkiej do gospodarki bazującej na usługach i rozwoju sektorów przemysłu tzw. wysokiej techniki jest uważane za jeden z objawów rozwoju gospodarczego (Jasiński, 2011; Dzikowski, 2015; Śliwa, Waląg, Tabor, 2016). Technika ta u podstaw ma wykorzystywanie nowoczesnych rozwiązań technologicznych, wynalazków, efektywniejszych podzespołów czy komponentów. Rzecz jasna wiąże się to z diametralną zmianą w obszarze zatrudnienia i kształcenia (Sobczak, 2013: 128). By rozwiązania te, których wdrożenie poprzedzone było zwykle kosztownymi i mozolnymi działaniami badawczymi, były opłacalne, stosuje się do nich ochronę praw własności - zwykle ochronę patentową (Turek, 2013: 231). W tym ujęciu aktywność patentowa może być traktowana jako miara aktywności innowacyjnej - obrazującej rozwój technologiczny danego obszaru (Acs, Audretsch, 1989: 171).

Funkcjonujący obecnie podział polityczny świata jest wynikiem różnego typu działań natury politycznej, czasami militarnej. Organizacja państw uzależniona jest od czynników historycznych, administracyjno-prawnych, geograficznych itd. Uogólnianie na cały obszar danego państwa niektórych wyników uzyskanych dla poszczególnych regionów, funkcjonujących w ich obrębie, wydaje się być obarczone dość znacznymi błędami. Mimo długoletniej współpracy i funkcjonowania w jednym organizmie państwowym podział regionalny często jest stale wyraźny i wręcz kultywowany. Dotyczy to większości obszarów - Flandrii i Walonii w Belgii czy Kastylii i Katalonii w Hiszpanii. Nawet w Polsce podział ten, mimo że jest wynikiem odgórnego podziału administracyjnego, w dużej mierze bazuje na regionach funkcjonujących od kilkuset lat. Specyfika tych regionów, dziedzictwo kulturowe i sposób podejścia do życia mieszkańców nieco się od siebie różnią.

W świetle tych informacji zasadne wydaje się być wykorzystywanie (o ile to możliwe) danych gromadzonych na poziomie regionalnym $\mathrm{w}$ analizach poszczególnych gospodarek (Niklewicz-Pijaczyńska, 2014: 334). Dostępny zasób metod ekonometrycznych - głównie z zakresu ekonometrii przestrzennej - dostarcza narzędzi, które umożliwiają nie tylko modelowanie zjawisk o wspólnej specyfice dla całych państw czy wszystkich uczestników rynku, ale także wyizolowanie tych, które są specyficzne dla poszczególnych regionów. 


\section{AKTYWNOŚĆ PATENTOWA - ANALIZA KONWERGENCJI}

Analiza rozkładu aktywności patentowej w ujęciu regionalnym w poszczególnych państwach Organizacji Współpracy Gospodarczej i Rozwoju (OECD) ${ }^{1}$ wskazuje na ogólną tendencję wzrostową tego zjawiska przy różnych zmianach w zakresie konwergencji. W związku z tym analiza graficzna możliwa jest dopiero po znormalizowaniu wartości w czasie względem siebie. W badaniu ustalono wzorzec, który określony jest przez region posiadający najwyższy wskaźnik w danym państwie. Następnie pozostałe regiony odnoszone są do wzorca. Przykładowe zmiany w latach 1993-2011 przedstawiono na ryc. 1.

Ryc. 1. Zmiana odległości od wzorca w Szwecji i Czechach

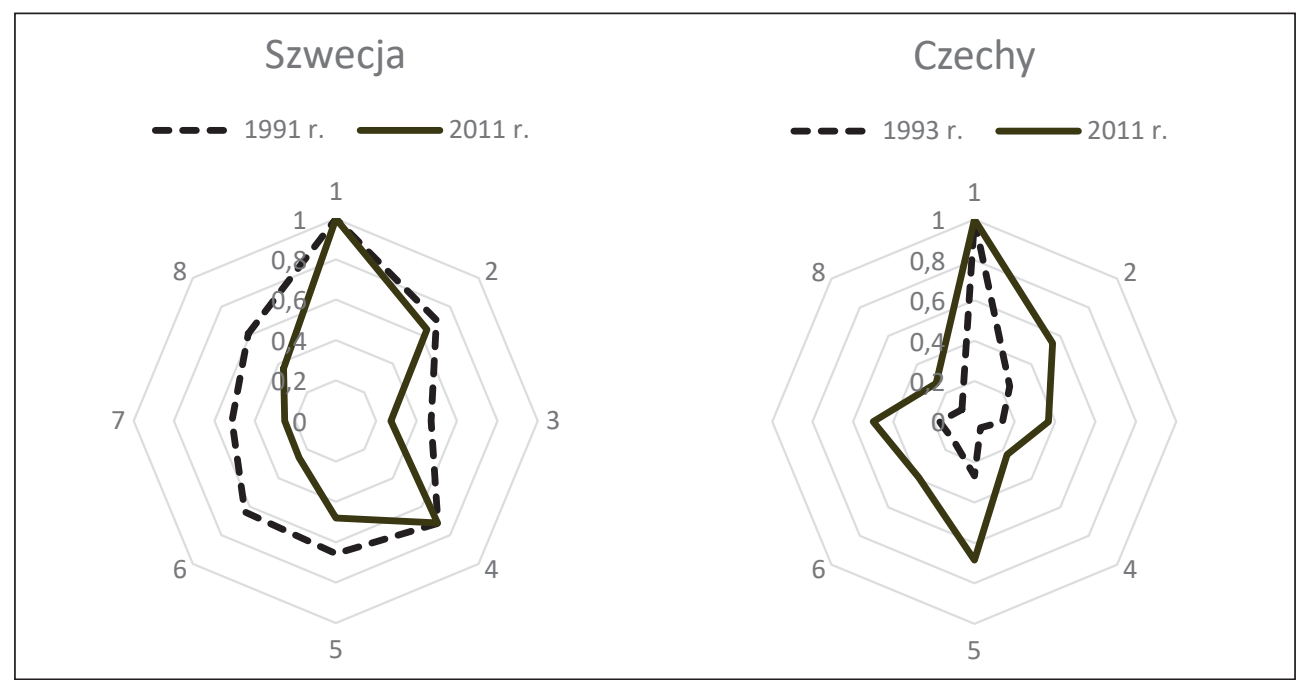

Źródło: opracowanie własne

Przedstawione na ryc. 1 informacje świadczą o wyraźnym przybliżeniu względem wzorca (wyznaczonego jako maksimum = 1) w Czechach w latach 1993-2011, przy jednoczesnym oddaleniu się - zawężeniu w kierunku „0” w Szwecji. W pierwszym przypadku zakładać można konwergencję, zaś w drugim dywergencję. Dla weryfikacji tej hipotezy w dalszym etapie badań wykorzystano model konwergencji bezwarunkowej (Strahl, 2010: 121) w postaci:

$$
\frac{1}{T}\left(\ln y_{i 0+T}-\ln y_{i 0}\right)=\alpha-\left[\frac{\left(1-e^{-\beta T}\right)}{T}\right] \ln \left(y_{i 0)}+\varepsilon_{i t},\right.
$$

${ }^{1}$ Spośród państw OECD (Australia, Austria, Belgia, Kanada, Chile, Czechy, Dania, Estonia, Finlandia, Francja, Niemcy, Grecja, Holandia, Węgry, Irlandia, Islandia, Izrael, Włochy, Japonia, Korea, Luksemburg, Łotwa, Meksyk, Nowa Zelandia, Norwegia, Polska, Portugalia, Słowacja, Słowenia, Hiszpania, Szwecja, Szwajcaria, Turcja, Wielka Brytania, Stany Zjednoczone Ameryki Północnej) i oczekujących (Kostaryka, Litwa, Rosja) jedynie Luksemburg, Nowa Zelandia, Słowenia, Litwa, Irlandia, Islandia i Łotwa nie wykazują podziału (większego niż na 2 regiony) umożliwiającego pomiar konwergencji, natomiast braki danych dotyczą Kostaryki i Rosji. 
gdzie: $\ln y_{i 0+T} i \ln y_{i 0}$ - odpowiednio badana kategoria $i$-tego $(i=1, \ldots, N)$ regionu w roku końcowym i początkowym,

$T$ - liczba lat, dla których liczona jest stopa wzrostu $(t=1, \ldots, T)$,

$\beta$ - parametr określający szybkość zbieżności,

$\varepsilon_{i t}$-składnik losowy.

Konwergencja występuje, gdy parametr $\theta$ obejmujący wyrażenie:

$$
\theta=-\frac{\left(1-e^{-\beta T}\right)}{T}
$$

jest istotny statystycznie, przyjmując jednocześnie wartość ujemną. Jej szybkość natomiast jest określana przez wartość parametru $\beta$ (tab. 1).

Tab. 1. Wyniki badania $\beta$-konwergencji dla regionalnej aktywności patentowej w poszczególnych państwach OECD (liczba patentów na tysiąc osób aktywnych zawodowo)

\begin{tabular}{|l|c|c|c|l|c|c|c|}
\hline \multicolumn{1}{|c|}{ Państwo } & \multicolumn{1}{c|}{$\theta$} & \multicolumn{1}{c|}{$\beta$} & \multicolumn{1}{c|}{$\mathrm{p}$} & \multicolumn{1}{c|}{ Państwo } & \multicolumn{1}{c|}{$\theta$} & \multicolumn{1}{c|}{$\beta$} \\
\hline Belgia & 0,515 & $-0,039$ & 0,697 & Korea & $-1,701$ & 0,026 & 0,150 \\
\hline Szwecja & 2,351 & $-0,034$ & 0,057 & Włochy & $-2,702$ & $0,030^{*}$ & 0,014 \\
\hline Holandia & 0,289 & $-0,028$ & 0,791 & Grecja & $-1,252$ & 0,034 & 0,337 \\
\hline Izrael & 0,490 & $-0,010$ & 0,658 & Słowacja & $-1,837$ & 0,039 & 0,208 \\
\hline Japonia & 1,268 & $-0,010$ & 0,240 & Niemcy & $-6,859$ & $0,042^{*}$ & 0,000 \\
\hline Norwegia & 0,091 & $-0,001$ & 0,931 & Hiszpania & $-3,716$ & $0,044^{*}$ & 0,002 \\
\hline Chiny & $-0,214$ & 0,003 & 0,832 & Węgry & $-4,428$ & $0,047^{*}$ & 0,007 \\
\hline Francja & $-0,592$ & 0,008 & 0,560 & Rosja & $-4,710$ & $0,052^{*}$ & 0,000 \\
\hline Finlandia & $-0,433$ & 0,009 & 0,694 & Australia & $-14,287$ & $0,054^{*}$ & 0,000 \\
\hline RPA & $-0,626$ & 0,011 & 0,551 & Austria & $-1,627$ & 0,055 & 0,148 \\
\hline Kanada & $-1,291$ & 0,015 & 0,233 & Meksyk & $-2,648$ & $0,062^{*}$ & 0,013 \\
\hline USA & $-4,607$ & $0,018^{*}$ & 0,000 & Turcja & $-1,976$ & 0,066 & 0,064 \\
\hline Szwajcaria & $-1,416$ & 0,024 & 0,216 & Polska & $-2,312$ & $0,073^{*}$ & 0,037 \\
\hline Dania & $-0,871$ & 0,025 & 0,448 & Czechy & $-5,565$ & $0,074^{*}$ & 0,001 \\
\hline $\begin{array}{l}\text { Wlk. } \\
\text { Brytania }\end{array}$ & $-3,834$ & $0,025^{*}$ & 0,003 & OECD & $-6,463$ & $0,028^{*}$ & 0,000 \\
\hline
\end{tabular}

*Wartości istotne statystycznie na poziomie $\alpha=0,05$.

Źródło: opracowanie własne

Otrzymane wyniki wskazują wyraźnie na występowanie konwergencji - istotnej statystycznie w 11 przypadkach oraz w ujęciu zagregowanym. Najszybszą konwergencję dostrzega się $w$ Czechach $(\beta=0,074)$, zaś najwolniejszą (ale istotną) w USA $(\beta=$ $0,018)$. Jeżeli chodzi o dywergencję, pozornie dotyczy ona sześciu państw, ale nie jest istotną statystycznie. Jedyny przypadek zauważalnej na poziomie tendencji statystycznej dywergencji zanotowano dla Szwecji $(\beta=-0,034 ; p=0,057)$. W dalszej kolejności podjęto również próbę analizy konwergencji w zakresie wskaźników określających aktywność patentową realizowaną we współpracy wewnątrz kraju i w kooperacji z zagranicą (tab. 2). 
Tab. 2. Wyniki badania $\beta$-konwergencji dla aktywności patentowej realizowanej we współpracy

\begin{tabular}{|c|c|c|c|c|c|}
\hline \multirow{2}{*}{ Państwo } & \multicolumn{2}{|c|}{$\begin{array}{l}\beta \text {-konwergencja dla współpracy } \\
\text { na poziomie }\end{array}$} & \multirow{2}{*}{ Państwo } & \multicolumn{2}{|c|}{$\begin{array}{l}\beta \text {-konwergencja dla współpracy } \\
\text { na poziomie }\end{array}$} \\
\hline & kraju & zagranicy & & kraju & zagranicy \\
\hline Australia & $2,51 \% *$ & $1,73 \%$ & Japonia & $6,28 \% *$ & $-2,01 \%$ \\
\hline Austria & $16,74 \% *$ & $2,71 \%$ & Korea & $4,60 \%$ & $6,43 \% *$ \\
\hline Belgia & $12,42 \%$ & $-0,86 \%$ & Meksyk & - & - \\
\hline Kanada & $11,54 \% *$ & $-0,01 \%$ & Holandia & - & $-1,74 \%$ \\
\hline Chile & $1,75 \%$ & - & Norwegia & $12,79 \% *$ & $3,07 \%$ \\
\hline Czechy & - & $12,03 \% *$ & Polska & $7,01 \% *$ & $13,42 \% *$ \\
\hline Dania & $12,88 \% *$ & $4,30 \%$ & Portugalia & $-3,99 \%$ & $9,43 \%$ \\
\hline Finlandia & $1,22 \%$ & - & Słowacja & $11,03 \%$ & $3,20 \%$ \\
\hline Francja & - & $3,52 \% *$ & Hiszpania & - & - \\
\hline Niemcy & $11,16 \% *$ & $3,28 \% *$ & Szwecja & - & $3,23 \% *$ \\
\hline Grecja & - & - & Szwajcaria & $9,80 \% *$ & $7,23 \% *$ \\
\hline Węgry & - & $2,99 \%$ & Wlk. Brytania & - & $2,91 \% *$ \\
\hline Izrael & $4,49 \%$ & $10,79 \% *$ & USA & - & $2,53 \% *$ \\
\hline Włochy & - & $5,42 \% *$ & OECD & $5,34 \% *$ & $4,12 \% *$ \\
\hline
\end{tabular}

*Wartości istotne statystycznie na poziomie $\alpha=0,05$.

Źródło: opracowanie własne

Współpraca w zakresie rozwoju innowacyjności jest jednym z kluczowych czynników w dzisiejszym konkurencyjnym, ale i szybko dopasowującym się do rzeczywistości gospodarczej, świecie (Zioło, 2012: 16). Konwergencja we współpracy wewnętrznej obserwowana była w dziesięciu na 17 państw (dla których dostępne są dane), natomiast odnośnie do współpracy zagranicznej - w 12 na 23 państwa. W obu przypadkach nie zaobserwowano istotnej statystycznie dywergencji. Można zatem zakładać, że w tym ujęciu - w zakresie współpracy - obserwowane dobre wzorce przenoszone są na inne regiony i współpraca, tak krajowa, jak i zagraniczna, rozwija się w coraz większym zakresie.

W dalszych badaniach założono, że państwa (i regiony) OECD traktować można jako względnie podobne w odniesieniu do funkcjonowania sektora B+R. Dzięki temu istnieje możliwość wykorzystania danych panelowych dla regionów państw OECD.

\section{MODELOWANIE AKTYWNOŚCI PATENTOWEJ}

Aktywność patentowa wskazuje na istniejący w danym obszarze geograficznym potencjał innowacyjny. Oczywiście problemem jest sposób podejścia do tej aktywności. Rzecz jasna nie wszystkie wartościowe nowe rozwiązania poddawane są procedurze patentowej. W niektórych gałęziach produkcji zmiany zachodzą w tak szybkim czasie, że każda zwłoka we wdrożeniu do produkcji mogłaby spowodować nieodwracalne negatywne skutki dla całego przedsięwzięcia. Jednakże traktując rynek jako całość (w ujęciu globalnym), możemy przyjąć, że podobne zachowania obserwujemy we wszystkich obszarach na tym samym - względnie - poziomie natężenia. Zatem ewentualne błędy dotyczą podobnych poziomów. 
Pojawia się więc problem sposobu ewidencji - gromadzenia danych dotyczących patentów. Wydaje się to być nieco prostszym zadaniem, jednakże na świecie istnieje wiele jednostek przyznających ochronę patentową. Pomijając lokalne - krajowe instytucje, jako międzynarodowe traktować należałoby World Intellectual Property Organization (WIPO) i The European Paten Office (EPO). Tymczasem często w literaturze spotykamy odniesienie do United States Patend Trade Office (USPTO) jako instytucji obejmującej działania na najbardziej rozwiniętym - w ujęciu konkurencyjnym - rynku. Co do potencjału finansowego na pierwsze miejsce wysuwa się rynek chiński - jednakże kwestie ochrony własności intelektualnej (ze względu na system) są tam traktowane w sposób dość specyficzny. USPTO - ze względu na uwarunkowania wewnętrzne - staje się ostatnio coraz mniej drożnym systemem (Grupp, 2007: 510).

W zakresie kształtowania się badanego zjawiska przyjęto, że jego przebieg w czasie (w długim okresie) powinien być zbliżony do krzywej logistycznej. W praktyce bowiem aktywność ta zmienia się coraz szybciej, a w pewnym momencie chłonność rynku - mimo jego permanentnego rozwoju - ulega ograniczeniu. Co więcej, założyć można, że formuła ochrony patentowej, ochrony praw własności intelektualnej w obecnej formie może ulec wyczerpaniu i jej miejsce zajmie innego rodzaju norma prawna. Funkcja logistyczna charakteryzuje się zatem zmiennym tempem przyrostów. Badane regiony również różnią się od siebie i to w sposób znaczący nawet w obrębie tego samego państwa.

Wstępna analiza danych dotyczących aktywności patentowej (ryc. 2) wskazuje na to, że poszczególne gospodarki państw znajdują się na różnych etapach wzrostu. W związku z tym przyjęto, iż w funkcji logistycznej wyróżnić możemy trzy etapy zmian (Szajt, 2006: 236): zbliżony do wykładniczego w pierwszej fazie, zbliżony do liniowego $\mathrm{w}$ drugiej fazie i zbliżony do logarytmicznego w trzeciej fazie. Bez względu na fazę obserwowany kształt przybliżyć można funkcją potęgową, zakładając, że może mieć ona różną - dostosowującą się, potęgę. $Z$ tego też względu jako właściwą postać analityczną dla badanego problemu zaproponowano funkcję potęgową.

Mimo postulowanego w literaturze zrównoważonego rozwoju (Bartkowiak, Dudek, Wszendybył-Skulska, 2016) zauważyć należy, że poszczególne jednostki administracyjne charakteryzują się specyficznymi warunkami, predestynującymi je do konkretnych rozwiązań w zakresie organizacji filarów rozwoju. Rozwój ten bazować może na turystyce, przemyśle wydobywczym lub usługach w zakresie IT. Bez względu jednak na specyfikę regionu pożądana jest odpowiednia dywersyfikacja źródeł dochodu. Poziom homogeniczności gospodarki nie został określony, jednakże zagrożenia, wynikające z możliwości ograniczeń korzyści płynących z wiodącego sektora, uzasadniają tego typu rozumowanie.

$\mathrm{W}$ tym miejscu pojawia się właśnie sektor B+R - traktowany jako motor innowacyjności. Jest on bowiem uważany za motor rozwoju w odniesieniu do bardzo wielu dziedzin działalności człowieka i w długim okresie założyć można jego rentowność. W przeciwieństwie do innych sektorów sektor B+R nie jest podatny na koniunkturę (w ujęciu ogólnym), a jedynie kierowane do niego środki finansowe są niekiedy ograniczane w związku z niekorzystnym kształtowaniem się innych czynników. Oczywiście produktywność sektora $\mathrm{B}+\mathrm{R}$ nie jest łatwa w pomiarze, a jego wpływ na gospodarkę w długim okresie - mimo iż niezaprzeczalny - także jest trudny do punktowego wychwycenia. 
Ryc. 2. Aktywność patentowa wybranych państw w latach 1993-2011
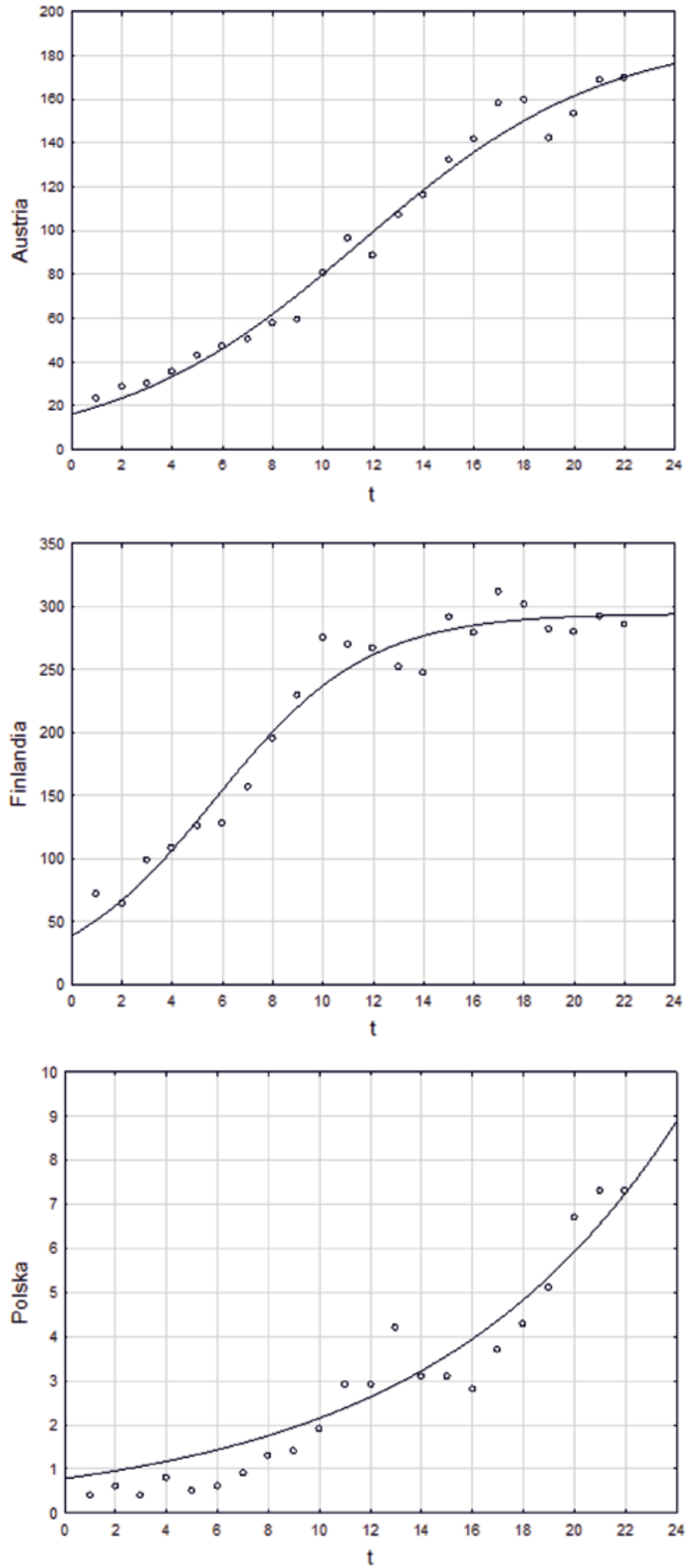

Żródło: opracowanie własne z wykorzystaniem pakietu STATISTICA 12.5 
Zakładając zatem podobne dążenia ze strony podmiotów funkcjonujących we wszystkich regionach, można przyjąć, że modelowanie w oparciu o próbę wykorzystującą dane dla wszystkich regionów w określonym czasie mogą być uzasadnione. Co więcej, konstrukcja modelu przestrzenno-czasowego z dekompozycją wyrazu wolnego w przestrzeni umożliwia wychwycenie różnic pomiędzy poszczególnymi regionami. Mimo iż poziom rozwoju gospodarczego (i nie tylko) poszczególnych regionów jest bardzo silnie zróżnicowany, zakłada się, że badane relacje pomiędzy zmienną endogeniczną, jaką jest aktywność patentowa, i zmiennymi egzogenicznymi, jakimi w proponowanym modelu są nakłady na działalność $\mathrm{B}+\mathrm{R}$ i personel zatrudniony w sektorze, kształtują się w sposób podobny (Ostraszewska, Tylec, 2016: 198). Natomiast różnice pomiędzy poszczególnymi regionami zostaną wychwycone poprzez zindywidualizowane wyrazy wolne.

Prezentowane ujęcie ma charakter analizy mezoekonomicznej. Posiadane wartości odnoszone są do wielkości zagregowanych dla całego obszaru (regionu). Nie można zatem wychwycić wpływu poszczególnych podmiotów, a jedynie funkcjonowanie ich razem, jako całości, $w$ badanym układzie. $Z$ drugiej strony, analizując poszczególne wyniki, otrzymujemy informacje, których wyjaśnienie jest możliwe przy dysponowaniu dodatkową wiedzą, która powinna uzasadniać te rezultaty - urealniać wnioski w świetle posiadanych informacji. Odniesienie wielkości nakładów do PKB (całość w ujęciu regionalnym) pokazuje aktywność aktorów regionalnego systemu innowacyjnego w odniesieniu do potencjału ekonomicznego tego obszaru. Przy zrównoważonym rozwoju - bez względu na poziom tego rozwoju - relacje nakładów brutto na działalność $\mathrm{B}+\mathrm{R}$ do $\mathrm{PKB}$ powinny być $\mathrm{w}$ poszczególnych regionach niemal jednakowe.

Z kolei personel zatrudniony w sektorze B+R to zarówno badacze, jak i technicy. $\mathrm{Z}$ jednej strony to na badaczach spoczywa największa odpowiedzialność za działania kreatywne. Jednakże w ujęciu ogólnym (także ze względu na dostępność danych) wielkość personelu jest również determinantą aktywności. Część działań badawczych nie mogłaby się odbyć bez wsparcia personelu technicznego. Ponadto $w$ wielu jednostkach to właśnie personel $\mathrm{B}+\mathrm{R}$ umożliwia funkcjonowanie poszczególnych jednostek badawczych. W trakcie badań lub eksperymentów badacze wykorzystywani są często jedynie w najbardziej wrażliwych etapach procesu, a w pozostałych badania realizowane są przez wyspecjalizowany personel techniczny. Co więcej, personel ten często wykonuje zadania, których realizacja przez badaczy jest niemożliwa lub zbyt kosztowna.

Układ w zakresie struktury zatrudnienia badacze-technicy powinien być odpowiednio zbilansowany. Przyjmując, że przedsiębiorstwa oraz instytucje publiczne zaangażowane $w$ działalność $B+R$ działają racjonalnie w obszarze zatrudnienia, możemy zatem przyjąć, że poziom zatrudnienia obu grup jest adekwatny do podziału zadań i ich właściwej realizacji. W tym ujęciu liczebność całego personelu jest traktowana jako liczebność homogenicznej grupy pracowników zaangażowanych w działalność B+R na jej różnych poziomach. Rzecz jasna w działalność innowacyjną zaangażowani są również pracownicy pionu produkcji czy marketingu, jednakże problem rozważany jest nie na poziomie wdrożenia czy realizacji produkcji, a na poziomie zaistnienia wartościowego rozwiązania objawiającego się złożonym wnioskiem patentowym.

W pracy zaproponowano następującą postać modelu:

$$
\begin{aligned}
\Delta \log P A T_{i t}= & \alpha_{i}^{\prime}+\left(\rho_{1}-1\right)\left(\log P A T_{i t-1}-\delta_{1} \log G E R D_{i t-1}-\delta_{2} \log P E R S_{i t-1}\right) \\
& +\gamma_{4} \Delta \log \beta_{1} G E R D_{i t}+\gamma_{5} \Delta \log \beta_{2} P E R S_{i t}+\xi_{i t}
\end{aligned}
$$


gdzie:

$P A T_{i t}$ - liczba patentów zgłoszonych przez rezydentów na terenie danego regionu $i$ w przeliczeniu na liczbę mieszkańców w okresie $t$, $G E R D_{i t}$ - wydatki brutto na działalność $\mathrm{B}+\mathrm{R}$ jako procent $\mathrm{PKB}$ w regionie $i \mathrm{w}$ okresie $t$, $P E R S_{i t}$ - personel sektora $\mathrm{B}+\mathrm{R}$ według ekwiwalentu pełnego zatrudnienia w przeliczeniu na liczbę zatrudnionych $\mathrm{w}$ regionie $i \mathrm{w}$ okresie $t$.

Estymacje przeprowadzono z wykorzystaniem pakietu GRETL.

Tab. 3. Wartości ocen parametrów modelu w postaci potęgowej

\begin{tabular}{|c|c|c|c|}
\hline Zmienna & Parametr & $\begin{array}{c}\text { Ocena } \\
\text { parametru }\end{array}$ & p-value \\
\hline$P A T_{i t-1}$ & $\alpha_{1}$ & 0,5022 & $<0,0001$ \\
\hline$G E R D_{i t-1}$ & $\delta_{1}$ & 0,3592 & $<0,0001$ \\
\hline$P E R S_{i t-1}$ & $\delta_{2}$ & 0,7452 & $<0,0001$ \\
\hline$\triangle G E R D_{i t}$ & $\beta_{1}$ & 0,1830 & $<0,0001$ \\
\hline$\triangle P E R S_{i t}$ & $\beta_{2}$ & 0,1823 & $<0,0001$ \\
\hline
\end{tabular}

Źródło: opracowanie własne z wykorzystaniem pakietu GRETL

Otrzymane rezultaty wskazują na wysoki poziom elastyczności długoterminowej aktywności patentowej względem nakładów na działalność B+R i personel badawczy oraz również istotną - lecz nieco słabszą - krótkoterminową elastyczność względem tych zmiennych. Ważniejsze jednak z punktu widzenia prezentowanego modelu było uzyskanie wartości zdekomponowanych wyrazów wolnych - charakterystycznych dla wybranych regionów.

Wartości wyrazów wolnych w prezentowanym modelu charakteryzują się wysokim poziomem zróżnicowania (ryc. 3) zarówno w ujęciu ogólnym, jak i w odniesieniu

Ryc. 3. Rozkład zdekomponowanych wyrazów wolnych dla 271 regionów państw OECD

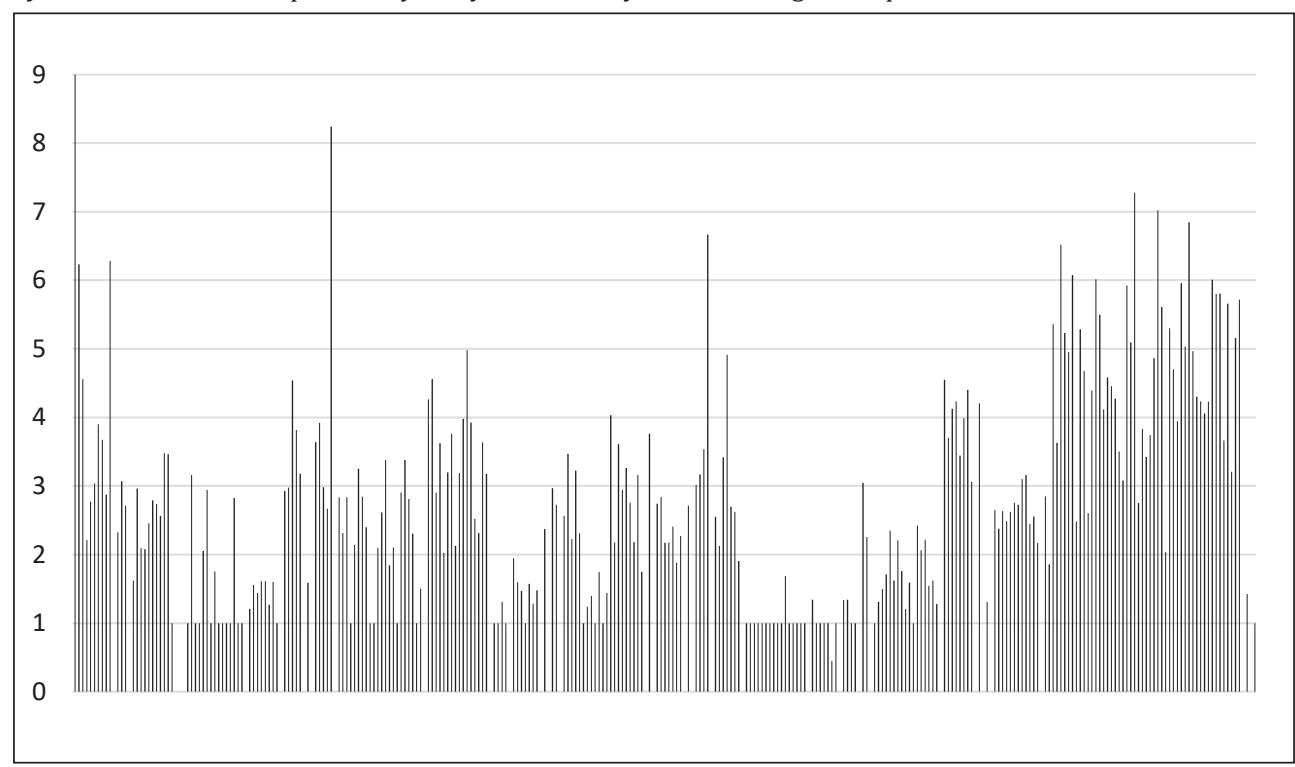

Źródło: opracowanie własne 
Ryc. 4. Rozkład średnich poziomów zdekomponowanych wyrazów wolnych dla państw OECD

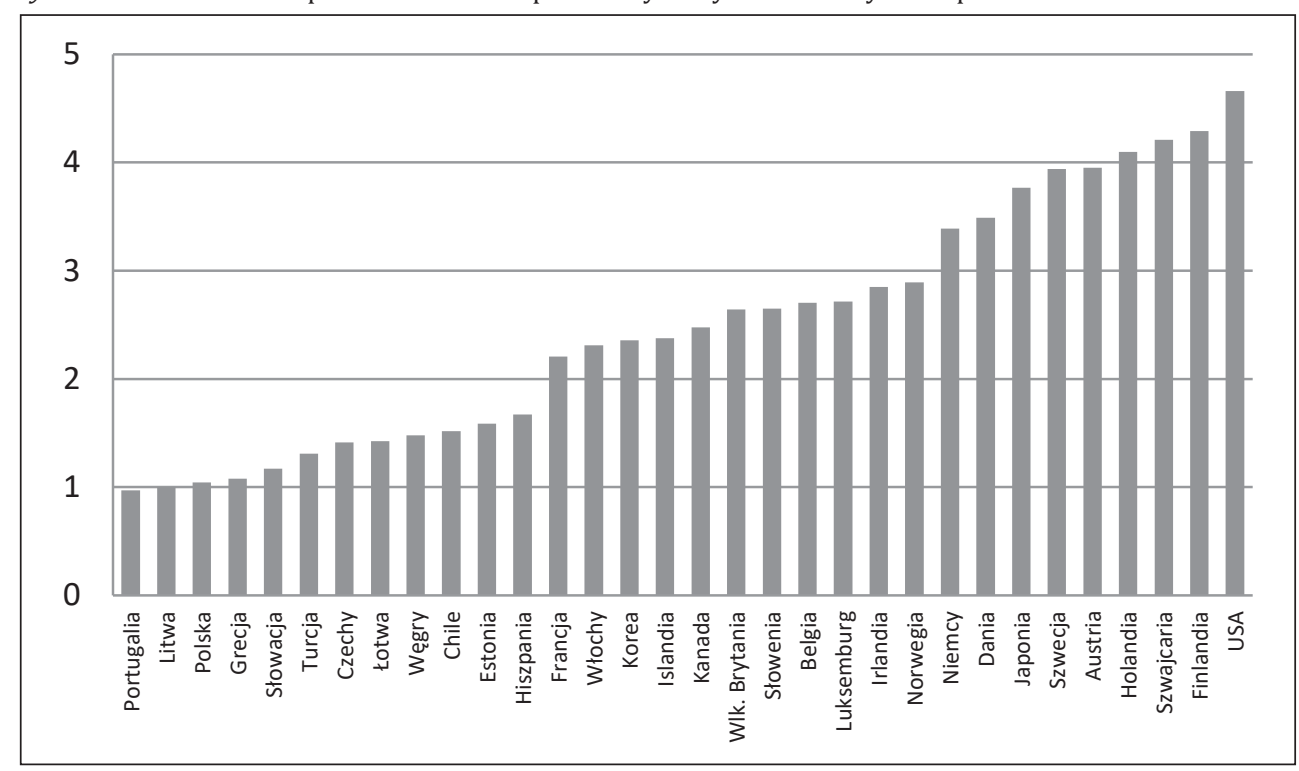

Źródło: opracowanie własne

do poszczególnych państw. Wartości te wchodzą do modelu w sposób multiplikatywny, a zatem zwielokrotniają oddziaływanie pozostałych zmiennych - o ile ich wartość jest większa od jedności. Dotyczy to niemal wszystkich regionów - wyjątek stanowią jedynie Azory $(0,45)$.

Z punktu widzenia gospodarki jako całości prześledzić można średni poziom wspomnianych ocen. Najniższy jest on dla Portugalii, Litwy, Polski i Grecji. Miejsce Polski w tym zestawieniu nie wydaje się być zaskoczeniem (Nowak, 2012: 167). Najwyższy poziom obserwujemy dla USA, Finlandii i Szwajcarii. Różnica wskazuje na fakt, że przy jednakowych nakładach na działalność B+R i zatrudnieniu w tym sektorze efekty w USA będą o około 5 razy wyższe niż przykładowo w Portugalii. Zauważalne jest występowanie pewnych wspólnych poziomów innowacyjności - jeżeli wspomniane wyrazy wolne traktować będziemy jako właśnie takie wskaźniki. Pierwsza grupa to państwa, dla których średni poziom zdekomponowanych wyrazów wolnych - wzmacniających efekt nakładów - nie przekracza 1,7. Kolejna to państwa o wzmocnieniu nakładów w wyniku pewnego poziomu innowacyjności o 2,2-2,9 razy. Ostatnia - liderzy, to te państwa, w których średni poziom wzmocnienia zaczyna się od 3,3-krotności.

\section{Podsumowanie}

Niezaprzeczalnym faktem jest wzrost poziomu innowacyjności zarówno na poziomie lokalnym, jak i w ujęciu globalnym. Realizacja celu badań - analiza poziomu innowacyjności państw OECD na poziomie regionalnym w latach 2000-2011 - umożliwiła wskazanie dużych rozbieżności nie tylko pomiędzy poszczególnymi państwami, ale i pomiędzy regionami. Potwierdzono, że najwyższy poziom innowacyjności jest w USA, Finlandii i Szwajcarii. Państwa o najwyższej innowacyjności korzystają z dotychczasowego dorobku i oddalają się od pozostałych. Silniej rozwinięte państwa i regiony, 
mimo zrozumiałego spowolnienia (wynikającego z osiągniętego wcześniej poziomu), korzystają z wykreowanego potencjału i trzymają niemal trwały dystans względem pozostałych. Jednakże poszczególnym krajom na poziomie rosnącej innowacyjności towarzyszy zwykle konwergencja. Obserwuje się niekiedy odwrotną tendencję, jednakże trudno mówić o jej nasileniu, częściej do czynienia mamy z powstrzymywaniem konwergencji niż z dywergencją. Zmiany w poziomie innowacyjności i dystansie pomiędzy poszczególnymi obszarami dostrzegalne są na poziomie poszczególnych grup obejmujących państwa o podobnym potencjale. W ujęciu ogólnym konwergencja aktywności patentowej jest faktem potwierdzonym.

\section{Literatura \\ References}

Acs, Z.J., Audretsch, D.B. (1989). Patents as a Measure of Innovative Activity. Kyklos, 42, 171-180. DOI:10.1111/j.1467-6435.1989.tb00186.x

Bartkowiak, P., Dudek, D., Wszendybył-Skulska, E. (2016). Koncepcja społecznej odpowiedzialności i koncepcja zrównoważonego rozwoju w procesie funkcjonowania organizacji. Kraków: Wydawnictwo Uniwersytetu Jagiellońskiego.

Dzikowski, P. (2015). Sieci dostaw a aktywność innowacyjna przemysłu wysokiej techniki w Polsce. Studia Ekonomiczne. Zeszyty Naukowe Uniwersytetu Ekonomicznego w Katowicach, $225,74-84$.

Grupp, H. (2007). Typology of science and technology indicators. W: H. Hanusch, A. Pyka (red.). Elgar companion to neo-Schumpeterian economics. Edward Elgar Publishing, 503-524.

Jasiński, L.J. (2011). Sektory przemysłu i wiedzy. Ewolucja struktury gospodarki. Warszawa: Oficyna Wydawnicza Politechniki Warszawskiej.

Niklewicz-Pijaczyńska, M. (2014). Aktywność innowacyjna i patentowa w ujęciu regionalnym. Przedsiębiorczość i Zarzq̨dzanie, 15(10), cz. 2, 333-343.

Nowak, P. (2012). Poziom innowacyjności polskiej gospodarki na tle krajów UE. Prace Komisji Geografii Przemysłu Polskiego Towarzystwa Geograficznego, 19, 153-168.

Ostraszewska, Z., Tylec, A. (2016). Nakłady na innowacje a poziom innowacyjności polskiej gospodarki. W: S. Kowalska, J. Rubik (red.). Zarzq̨dzanie kosztami przedsiębiorstwa w kontekście społecznej odpowiedzialności biznesu. Częstochowa: Wydawnictwo Wydziału Zarządzania Politechniki Częstochowskiej, 189-199.

Sobczak, E. (2013). Efekty strukturalne zmian zatrudnienia według sektorów zaawansowania technologicznego w regionach europejskich. Prace Naukowe Uniwersytetu Ekonomicznego we Wrocławiu, 285, 123-133.

Strahl, D. (2010). Innowacyjność europejskiej przestrzeni regionalnej a dynamika rozwoju gospodarczego. Wrocław: Wydawnictwo Uniwersytetu Ekonomicznego we Wrocławiu.

Szajt, M. (2006). Modeling of State Innovativeness Based on Space-time Models. Dynamic Econometric Models, 7, 231-238.

Śliwa, R., Waląg, P., Tabor, S. (2016). Ewolucja struktur produkcji i zatrudnienia w gospodarkach rynkowych. Wnioski dla Polski. Prace Komisji Geografii Przemysłu Polskiego Towarzystwa Geograficznego, 30(3), 45-58.

Turek, I. (2013). Znaczenie i wycena wartości niematerialnych i prawnych w działalności innowacyjnej przedsiębiorstwa. Zeszyty Naukowe Uniwersytetu Szczecińskiego. Finanse. Rynki finansowe. Ubezpieczenia, 61(2), 229-238.

Zioło, Z. (2012). Miejsce innowacyjności w kształtowaniu procesów rozwoju gospodarczego układów przestrzennych. Prace Komisji Geografii Przemysłu Polskiego Towarzystwa Geograficznego, 20, 9-32.

Marek Szajt, dr hab. prof. Politechniki Częstochowskiej, kierownik Katedry Ekonometrii i Statystyki na Wydziale Zarządzania. Jego zainteresowania naukowo-badawcze dotyczą w szczególności: badania innowacyjności na poziomie mikro, mezo i makro, badań przestrzennych, analiz symulacyjnych, modelowania 
ekonometrycznego z wykorzystaniem prób przestrzenno-czasowych. Autor i współautor ponad 100 publikacji naukowych oraz raportów wykonywanych na zlecenie instytucji samorządowych i przedsiębiorstw.

Marek Szajt, Ph.D., an associate professor of the Czestochowa University of Technology and the Head of the Department of Econometrics and Statistics of Faculty of Management. His research interests relate, in particular to the study of innovation in the micro-, meso- and macro scale, spatial research, simulation analysis, econometric modelling using spatio-temporal sample. Author and co-author of over 100 publications and reports carried out on behalf of local government institutions and enterprises.

\section{Adres/address:}

Politechnika Częstochowska

Katedra Ekonometrii i Statystyki

Wydział Zarządzania

Al. Dąbrowskiego 69, 42-201 Częstochowa, Polska

e-mail: marszajt@zim.pcz.pl 